\title{
Fasciolosis effects on the metabolic profile in Creole cattle in M éxico
}

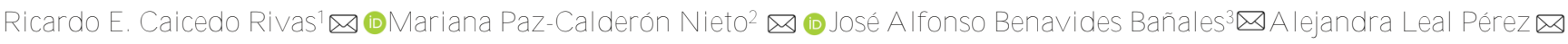

Laboratorio de Endocrinología de la Reproducción y Malacología, Facultad de Ciencias Biológicas;

Benemérita Universidad Autónoma de Puebla. Puebla. México

\begin{abstract}
A bstract. Diseases caused by parasites reduce productive and reproductive activities in native animals and even more so in animals destined for human consumption, such as cattle, one of these diseases is fasciolosis, caused by Fasciola hepatica, whose prevalence is estimated between 23.5 to $33 \%$ in very humid areas with temperatures that vary between $15.5 \pm 1.1$ to $34.1 \pm 2.1^{\circ} \mathrm{C}$., At altitudes that fluctuated between 300 and 2400 masl. The objective of this study was to determine the pathophysiological changes (histological analysis and obtain the number of flukes in liver parenchyma, metabolic and enzymatic profile and differential leukocyte count) in creole cattle in different zoogeographic areas in México; blood and liver tissue samples were taken from 7892 Creole animals. Results: the prevalence of fasciolosis was $48.9 \%$; in macro histopathology: hepatic obstructions were detected, an increase in the diameter and thickening of the bile ducts (cholangiohepatitis), a decrease in the thickness of the left and ventral hepatic lobes, and in chronic cases, liver cirrhosis was observed; at the histological level: loss of cell morphology and the presence of $F$. hepatica eggs were observed, deposited in the liver parenchyma and in the blood and bile ducts. It was found that liver damage was directly proportional to the number of flukes found and that these also caused alterations in blood biochemical components. The biochemical parameters in blood were altered in a very significant way $(P<0.05$ and $P<0.01)$, these altered parameters were: Urea / BUN, cholesterol and total proteins; enzymes such as: Y-GT, ALT / GPT, AST / GOT, LHD and alkaline phosphatase, detected in females and males; It is concluded that liver damage is directly proportional to the number of flukes present, and when compared with the metabolic profile, these are significantly al tered.
\end{abstract}

Key words: Fasciola hepatica, pathophysiology, liver damage, parenchyma, biochemical parameters.

\section{Efecto de la fasciolosis sobre el perfil metabólico en ganado Criollo en M éxico}

Resumen. Las enfermedades causadas por parásitos disminuyen las actividades productivas y reproductivas en los animales nativos y más aún en los animales destinados al consumo humano, como el ganado bovino, una de estas enfermedades es la fasciolosis, causada por Fasciola hepatica, cuya prevalencia se estima entre 23.5 a $33 \%$ en áreas muy húmedas con temperaturas que varían entre $15.5 \pm 1.1$ a $34.1 \pm 2.1 \stackrel{\circ}{\circ}$., a al titudes que fluctuaron entre 300 y 2 $400 \mathrm{msnm}$. El objetivo de este estudio fue determinar los cambios fisiopatológicos (análisis histológico y obtener el número de duelas en parénquima hepático, perfil metabólico y enzimático y conteo diferencial de leucocitos) en bovinos criol los en diferentes áreas zoogeográficas en México; se tomaron muestras de sangre y tejido hepático de 7 892 animales criollos. La prevalencia de fasciolosis fue de $48.9 \%$; en macro histopatología: se detectaron obstrucciones hepáticas, un aumento en el diámetro y engrosamiento de los conductos biliares (colangiohepatitis), una disminución en el grosor de los lóbulos hepáticos izquierdo y ventral, y en casos crónicos, se observó cirrosis hepática; a nivel histológico: se observó pérdida de la morfología celular y presencia de huevos de F. hepatica, depositados en el parénquima hepático y en los conductos sanguíneos y biliares. Se detectó que el daño hepático era directamente proporcional al número de trematodos encontrados y que estos también causaron alteraciones en los componentes bioquímicos sanguíneos. Los parámetros bioquímicos en sangre estuvieron al terados de manera muy significativa ( $P<0.05$ y $P<0.01$ ), estos parámetros alterados fueron: Urea / BUN, colesterol y proteínas totales; enzimas tales como: $\gamma$ - GT, ALT / GPT, AST / GOT, LHD y fosfatasa al calina, detectada en hembras y machos; se concluye que el daño hepático es directamente proporcional al número de distomas presentes, y al compararlo con el perfil metabólico, estos se alteran significativamente.

Palabras clave: Fasciola hepatica, fisiopatología, daño hepático, parénquima, parámetros bioquímicos

Recibido: 2020-08-01. Aceptado: 2020-12-07

${ }^{1}$ Corresponding author: ricaido@yahoo.com

${ }^{2}$ Complejo Regional Mixteca, (Sede Izucar de Matamoros), Benemérita Universidad Autónoma de Puebla, Boul evard Val sequillo and San Claudio Ave. Building Bio-1, Lab.347, C.P. 72570

${ }^{3}$ ESVIC-Corporativo México, Puebla. México 


\section{Introduction}

Mexico is one of the countries in Latin America with the highest number of ruminants (cattle and sheep, mainly), however, the ruminant population is affected by a parasitic disease called fasciolosis and which affects herbivorous animals, this parasitosis is caused by the parasite of the class Trematoda, family Fasciolidae: Fasciola hepatica (Dalton, 1999). This disease is emerging or re-emerging in many countries, and its prevalence, intensity, and geographic distribution are increasing (Mas-Coma, 2004). Fasciolosis is currently the vector-borne disease with the widest known latitudinal, longitudinal, and altitudinal distribution (Mas-Coma et al., 2003). This parasitosis affects many regions of Mexico, with a prevalence of $33.3 \%$ in cattle in very humid areas (tropical and subtropical) and $13.3 \%$ in sheep, and in buffaloes by $65 \%$ (Rangel y Martínez, 1994; Ortega et al., 2007; Caicedo et al., 2010); Nowadays this parasitosis has decreased its prevalence, in approximately 10 years, this decrease is due to the use of food additives mainly such as beta-adrenergic agonists ( $\beta 2-A A)$, it is now re-emerging and has been detected in animals with high levels of serum concentrations of $\beta 2-A A$ (Clenbuterol-Clb) in blood from $1253.5 \pm 87.5$ to $1850 \pm 123.4 \mathrm{ng} / \mathrm{ml}$ (Caicedo et al., 2009; Paz-Calderón et al., 2011; Caicedo et al., 2011, Saavedra et al., 2019); while in sheep its prevalence is lower because there are no definitive diagnostic studies of this disease in this species ruminant. Recently, in Mexico diagnostic and control techniques of this parasitosis were implemented, however these programs established by higher education entities have not encouraged government authorities to incorporate more resources for the study of this parasitosis and have not persisted its scope and repercussions in damage to national economic productivity. The purpose of this study was to evaluate the pathophysiological effects caused by $\mathrm{F}$. hepatica in native or creole cattle in different zoogeographic zones of Mexico.

\section{Material and Methods}

Blood samples and livers: Clinically healthy cattle (animals without flukes and without abnormalities at the liver (evel) and animals with fasciolosis slaughtered in different municipal slaughterhouses and private farms in Mexico were collected, for two years the population of sampled animals was 7892 cattle.

Histological analysis: The number of trematodes (flukes) in the liver parenchyma was determined by examining the affected livers. To observe the damage of liver parenchyma, liver tissue samples were taken and subjected to a histological process and stained with $\mathrm{H} \& \mathrm{E}$.

Blood samples: were taken to count white blood cells (differential count). The analysis of the metabolic profile was carried out in blood serum samples, macro minerals were measured as; Calcium/ $\mathrm{Ca}$ and phosphorus/ P, metabolites such as: Urea/ BUN, total Cholesterol (TC) and total Proteins (TP) and various enzymes were measured (gamma glutamyl transferase-yGT; alanine amino-transferase-ALT/ GPT; aspartate amino-transferase-AST/GOT; lactic dehydrogenase LDH; Alkaline phosphatase-ALP) and these metabolites were detected with different diagnostic kits (Bio-System-USA).

Statistical analysis of data obtained: An analysis of variance (ANOVA) with the statistical program Stat-2 was used (Olivares, 1994) and to determinate the significance between averages was used D uncan's new multiple range test.

\section{Results and D iscussion}

A) Number of flukes in the liver parenchyma: In the hepatic ducts of the livers confiscated in the municipal slaughterhouses, flukes were found in a variable number, with a minimum of 1 fluke and a maximum of 273 flukes per liver, in females the highest number of flukes collected was 54 , while in males it was 273. This variation is due to the number of metacercariae ingested by each animal (reinfestation, possibly, animals with a high number of worms), which was impossible to detect in this study due to the animals analyzed were naturally infected with $F$. hepatica.
Most of the confiscated livers showed a significant increase in the diameter of the hepatic ducts (Figure 1a); in addition, its color was whitish-yellowish, due to the obstruction of these ducts by the parasite (Figure $1 b)$, as well as the decrease in the thickness of the affected lobes (left and ventral) of approximately 30 $\mathrm{mm}$ (in normal livers this decrease does not occur, however, there is no history of this anomaly), since when the parasitic disease progresses there are losses in the consistency of the liver, caused by fibrosis and finally cirrhosis in very chronic cases (Figure $1 b, c)$. As a result, the liver loses its metabolic faculties and 
allows the accumulation of substances rich in salt, which crystallizes, causing obstruction of the ducts (Figure 1c), however, these ducts were obstructed by the presence of flukes within them, bringing favorable conditions for the reproduction of bacteria such as Clostridium spp (Robles, 1998), Escherichia coli,
Enterococcus faecalis, and Klebsiella pneumoniae (Valero et al., 2006). All the previous characteristics and based on the literature (Guy et al., 2001; Mas-Coma, 2005 and Caicedo et al., 2009) indicate that the majority of the animals with $F$. hepatica were with a chronic parasitic disease.

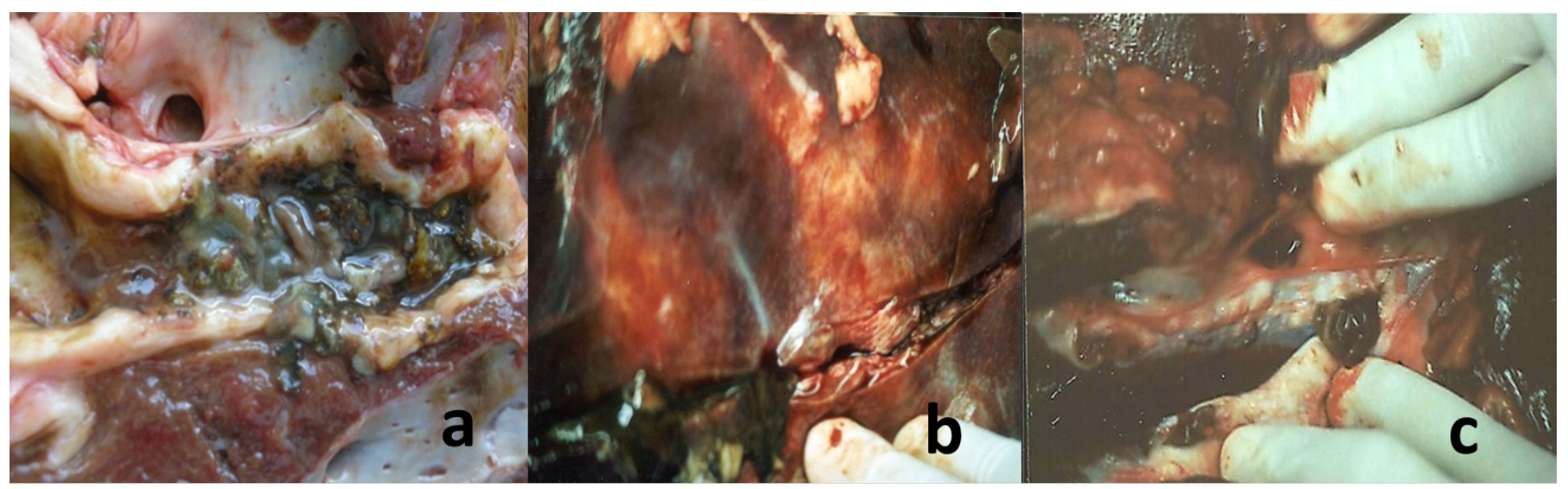

Figure 1. a) Opening of a hepatic duct where crystallized bileand flukes of $F$. hepatica are observed, b) change of the liver coloration (fibrosis-cirrhosis), and c) crystallization of bile fluid within liver ducts, this is cholangiohepatitis.

At the cellular level, compared to with clinically healthy liver tissue (Figure 2a), we could observe loss of the morphology, chronic hepatitis, inflammation forming micro-abscesses, proliferation of bile ducts, intracytoplasmic cholestasis, chronic inflammatory infiltrate based of lymphocytes, dilation of the sinusoids (Figure 2b), thickening of the Glisson's capsule by a chronic process, presence of fibroblasts, fibrosis, cirrhosis, and eggs of F. hepatica in the ducts and in the hepatic parenchyma (Figure 2c and d).

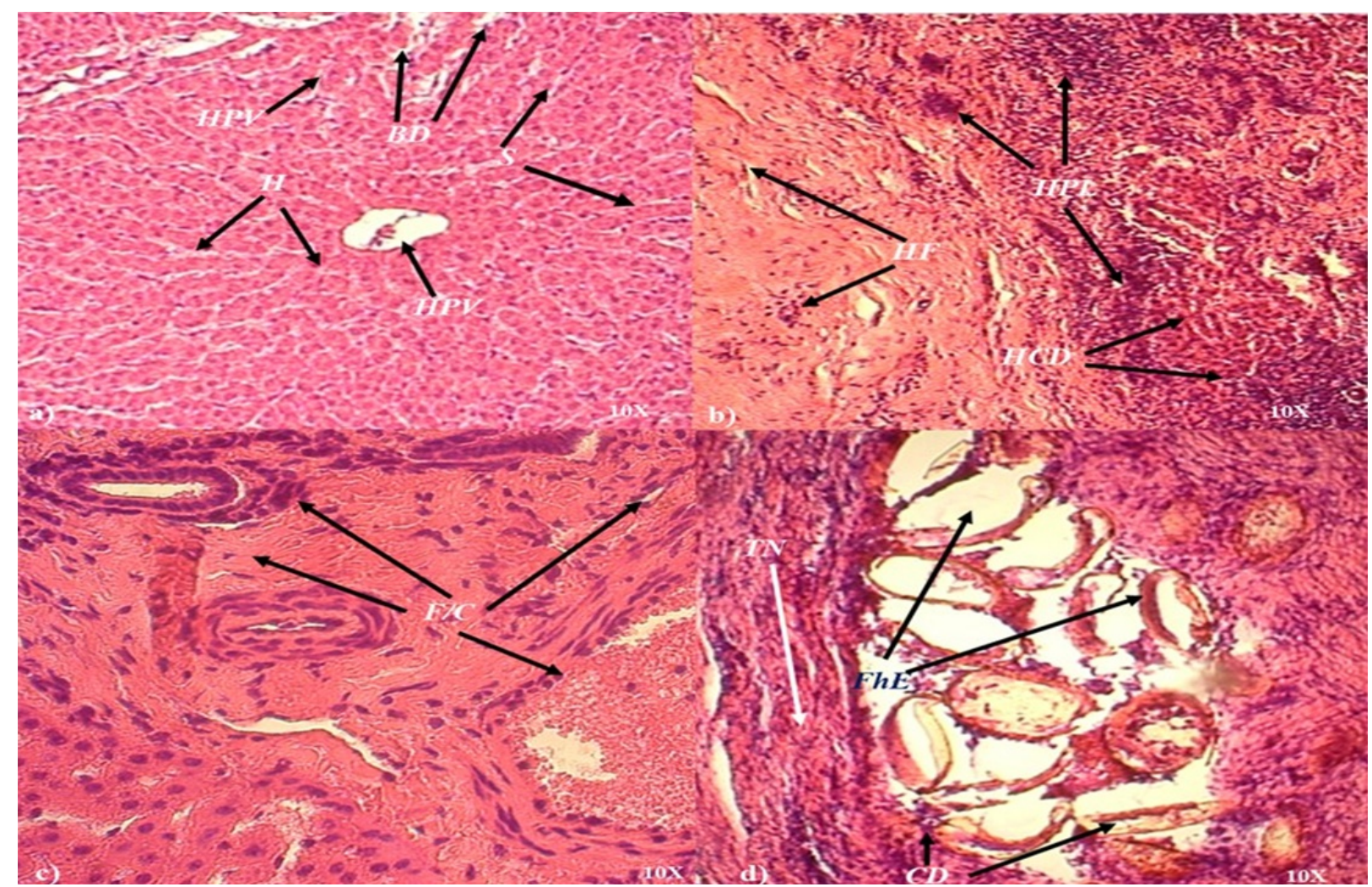

Figure 2: a) Section of clinically healthy creole bovine liver (animals without worms and without abnormalities at the liver level), showing hepatocytes $(H)$, sinusoidal ducts (S), bile ducts (BD), hepatic portal vein (HPV), terminal hepatic vein (THV). b) Section of the Creole bovine liver with fascioliasis, showing the presence of an inflammatory infiltrate with a predominance of lymphocytes (IIPL), proliferation of capillaries, hepatic fibrosis (F), hepatocyte cords with degenerative changes (HC). C) Replacement of the liver parenchyma by fibrosis and thickening of the capillary wall with an inflammatory infiltrate $(F / C)$, d) Accumulation of $F$. hepatica (Fh) eggs surrounded by tissue necrosis (TN) and cellular detritus (CD ), delimited by fibrous liver tissue (FT) with an inflammatory infiltrate. 
B) Differential recount: About the counting of white blood cells, we found significant differences $(P<0.01)$ in eosinophils values in the analyzed groups, also in monocytes in males (Table 1). According to the number of flukes, there were significant differences in males who presented a decrease of neutrophils, an increase of lymphocytes; and in both groups (males and females) there was a decrease of monocytes and an increase of eosinophils, (Table 2).

Table 1. Values of the counting of white blood cells of clinically healthy bovines (animals without flukes and without abnormalities at the liver level) and bovines with $F$. hepatica.

\begin{tabular}{|c|c|c|c|c|c|c|c|}
\hline & & $\mathrm{n}$ & $\begin{array}{c}\text { Neutrophils } \\
\%\end{array}$ & $\begin{array}{c}\text { Lymphocytes } \\
\%\end{array}$ & $\begin{array}{c}\text { Eosinophils } \\
\%\end{array}$ & $\begin{array}{c}\text { Monocytes } \\
\%\end{array}$ & $\begin{array}{c}\text { Basophills } \\
\%\end{array}$ \\
\hline \multirow{2}{*}{$\frac{\frac{y}{N}}{\Sigma}$} & Healthy & 992 & $54.9 \pm 1.6$ & $38.7 \pm 1.5$ & $2.0 \pm 0.3^{a}$ & $3.8 \pm 0.4^{a}$ & $0.6 \pm 0.1^{a}$ \\
\hline & F. hepatica & 996 & $47.8 \pm 3.0$ & $45.7 \pm 2.9$ & $4.3 \pm 1,1^{a}$ & $1.8 \pm 0.4^{b}$ & $0.3 \pm 0.1^{b}$ \\
\hline \multirow{2}{*}{$\frac{\frac{y}{0}}{\frac{\pi}{0}}$} & Healthy & 956 & $50.7 \pm 2.2$ & $43.8 \pm 2.0$ & $2.9 \pm 0.4^{b}$ & $2.4 \pm 0.4$ & $0.2 \pm 0.1^{a}$ \\
\hline & F. hepatica & 914 & $45.9 \pm 4.1$ & $42.1 \pm 3.8$ & $8.4 \pm 2.3^{a}$ & $2.3 \pm 0.4$ & $0.8 \pm 0.4^{b}$ \\
\hline
\end{tabular}

a, bDifferent letters show significant differences $(P<0.05$ and $P<0.01)$

Table 2. Values of the counting of white blood cells of bovines with $F$. hepatica according to the number of flukes into the liver and healthy bovine: animals without flukes and without abnormalities at the liver level.

\begin{tabular}{|c|c|c|c|c|c|c|c|}
\hline & No. of flukes & $\mathrm{n}$ & $\begin{array}{c}\text { Neutrophils } \\
\%\end{array}$ & $\begin{array}{c}\text { Lymphocytes } \\
\%\end{array}$ & $\begin{array}{c}\text { Eosinophils } \\
\%\end{array}$ & $\begin{array}{c}\text { Monocytes } \\
\% \\
\end{array}$ & $\begin{array}{c}\text { Basophils } \\
\%\end{array}$ \\
\hline \multirow{5}{*}{$\frac{\frac{y}{\sigma}}{\sum}$} & Healthy & 992 & $54.9 \pm 1.6^{a}$ & $38.7 \pm 1.5^{b}$ & $2.0 \pm 0.3$ & $3.8 \pm 0.4^{a}$ & $0.6 \pm 0.1^{a}$ \\
\hline & $1-10$ & 249 & $50.4 \pm 5.3^{a b}$ & $42.2 \pm 4.0^{b}$ & $4.8 \pm 0.26^{b}$ & $2.6 \pm 0.7$ & $0.0 \pm 0.0$ \\
\hline & $11-25$ & 301 & $49.8 \pm 2.8^{a b}$ & $43.0 \pm 3.7^{\mathrm{ab}}$ & $5.5 \pm 0.17^{b}$ & $1.3 \pm 0.6^{c}$ & $0.5 \pm 0.3$ \\
\hline & $26-50$ & 154 & $54.5 \pm 0.5^{a b}$ & $41.5 \pm 1.5^{b}$ & $6.5 \pm 0.5^{b}$ & $1.5 \pm 1.5^{b}$ & $0.0 \pm 0.0$ \\
\hline & $>51$ & 292 & $31.0 \pm 1.0^{b}$ & $64.0 \pm 1.0^{a}$ & $6.5 \pm 0.4^{b}$ & $1.5 \pm 0.5^{b}$ & $1.0 \pm 0.0$ \\
\hline$y$ & Healthy & 956 & $50.7 \pm 2.2$ & $43.8 \pm 2.0$ & $2.9 \pm 0.4^{b}$ & $2.4 \pm 0.4^{a}$ & $0.2 \pm 0.1$ \\
\hline$\overline{\bar{\sigma}}$ & 1-10 & 436 & $50.5 \pm 6.9$ & $44.4 \pm 6.0$ & $3.0 \pm 0.7^{b}$ & $1.9 \pm 0.6^{b}$ & $0.3 \pm 0.2$ \\
\hline 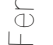 & $11-25$ & 478 & $45.0 \pm 2.0$ & $45.5 \pm 5.5$ & $8.0 \pm 0.8^{c}$ & $1.5 \pm 0.5^{c}$ & $0.0 \pm 0.0$ \\
\hline
\end{tabular}

a, b, cDifferent letters show significant differences $(P<0.05$ and $P<0.01)$

The increase in the number of eosinophils in animals with F. hepatica (Table 1 and 2) is consistent with the diagnostic characteristics of the disease (Guy et al., 2001; Mas-Coma, 2005); however, this increase is more evident during the parenchymal phase and these leukocyte blood cells tend to increase when the parasite enters the bile ducts and initiates rupture of the parenchyma, invading both the hepatic canaliculi and hepatic arterioles and venules over time, producing obstruction of these structures, resulting in cell death, apoptosis, fibrosis occurs, leukocyte inflammatory processes, there is a degeneration of liver tissue, loss of much of the metabolic functionality, the liver falls into cirrhosis, finally, liver dysfunction (Poitou et al., 1992, 1993; Jemli et al., 1993, Caicedo et al., 2009). It is also observed that among the white leukocyte cells: lymphocytes and eosinophils both increase their number in animals with Fasciola hepatica: males and females; the same happens when the values of animals with different numbers of flukes detected at the level of the hepatic parenchyma are analyzed $(P<0.05)$.

C) Metabolic profile: In relation to the metabolic profile, there were significant differences $(P<0.05$ and 0.01 , respectively), in the values of Urea / BUN and phosphorus between the two groups of males, while the females only in Urea / BUN (Table 3). The data obtained show that there were differences in the parameters between males and females and more when the data were correlated with the number of trematodes, as seen in table 3, there were more males with a greater number of trematodes in the liver than in females. Possibly here the immunological characteristics of the females play an important role, which is less susceptible to this parasitic infection, the values and metabolic differences are clearly observed. in Table 3 and 4. These data agree with Caicedo et al., 2009. 


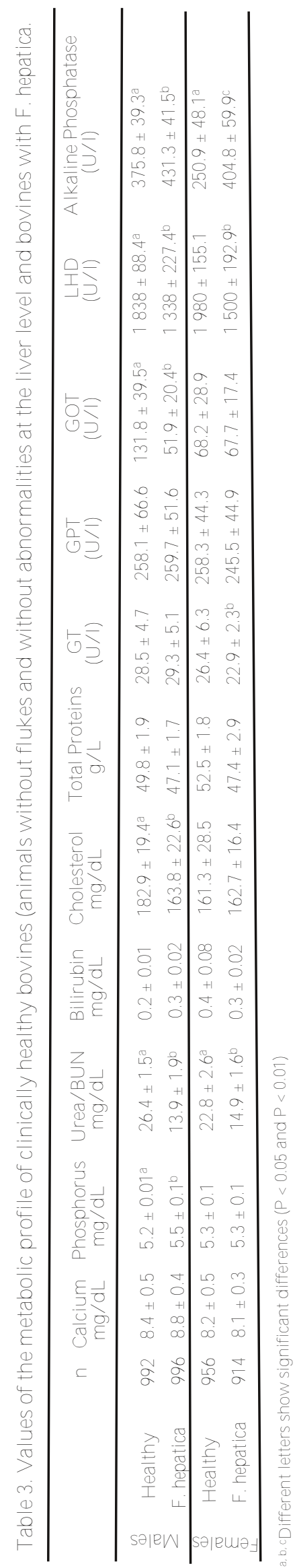

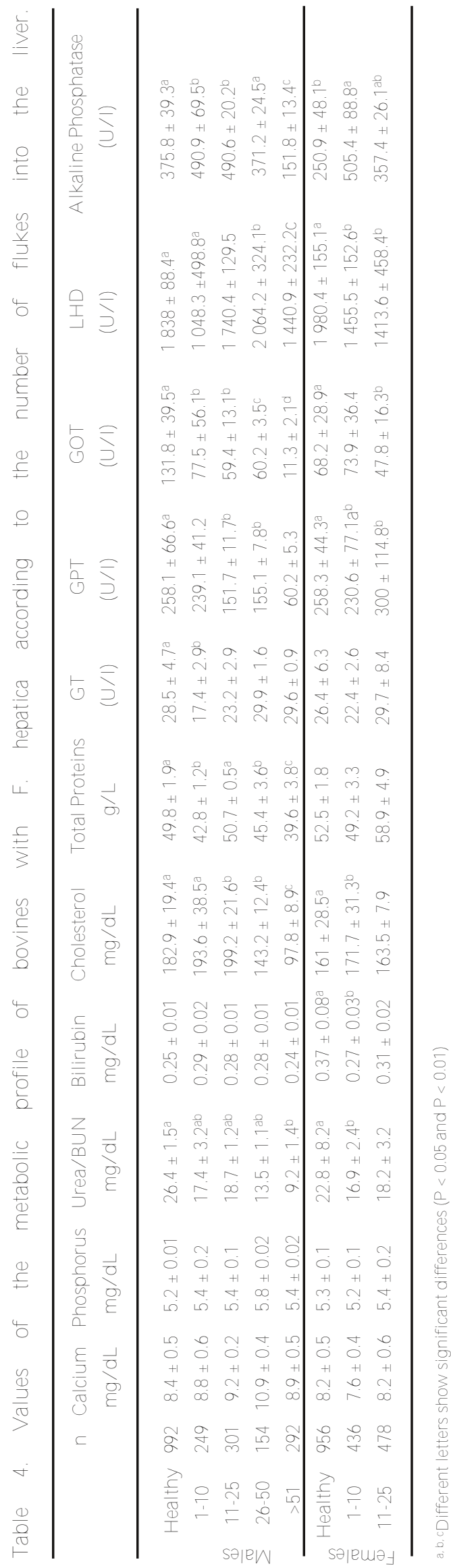


From the metabolic profile of the animals studied with fasciolosis grouped by the number of flukes located in the liver parenchyma (Table 4), it was detected that in males and females the bilirubin values decrease when the number of trematodes in the liver parenchyma increases. This agrees with Ortega et al., (2007); Torres, 2010 and Caicedo et al., (2010); this decrease in bilirubin concentrations in the blood is due to the accumulation of bile due to obstruction of the bile ducts, preventing it from entering the bloodstream due to the lack of biliary communication that is lost, in addition to the absence of hepatocytes due to the development of a fibrosis [begins with leukocyte inflammatory processes, cell death-apoptosis and finally there is growth of bacteria of the genus Clostridium spp, (Robles, 1998) and also in animals that are re-infested by Fasciola hepatica, this re-infestation does not lead to liver regeneration, developing cirrhosis itself with possible development of hepatitis, thus preventing the formation of bile at the level of the hepatocytes and the bile that forms tends to accumulate in the different structures of the liver parenchyma, hence the yellowing of the liver. On the other hand, the most important liver enzymes detected, were the values of alkaline phosphatase (ALP), alanine amino-transferase (ALT / GPT), Aspartate amino-transferase (AST / GOT), they showed decreasing values compared to clinically healthy animals (animals without flukes and without abnormalities at the liver level); while total cholesterol (TC) in males and AST / GOT in females showed a decreasing trend as well, when the number of trematodes in the liver increases; while lactic dehydrogenase (LHD) in males and females tends to decrease significantly $(P<0.05$ and $P<0.05)$, these data coincide with those of Caicedo et al., (2010); This decrease is due to the increase in flukes in the liver parenchyma, increasing the obstructions in the different structures, inhibiting the hepatic homeostatic activity of the animals, significantly affecting weight gain (Loyacano et al., 2002 and Caicedo et al., 2010); It is added that the increase in liver flukes also produces a decrease in reproductive and productive parameters, however, it does not cause the death of animals with a high degree of infestation and they become reservoirs for the transmission of Fasciola hepatica; finally the values obtained in this study are significant $(P<0.05$ and $\mathrm{P}<0.05$ ) (see Table 4).

As a result of the damage caused by fasciolosis in creole cattle in the studied areas. The data detected by histopathology and the metabolic profile show the great physiological influence that this parasitosis, fasciolosis, has in directly influencing the homeostatic mechanism of ruminants, however cattle do not die with a high degree of infestation and this will depend on the age of the animal, the younger, the more susceptible it is to irreversible damage to the liver. (Loyacano et al., 2002; Ortega et al., 2007; Caicedo et al., 2010); therefore, fasciolosis can be considered as a parasitic disease of great epidemiological importance, since it causes great damage to the animal and important economic losses to the farmer.

\section{Conclusion}

This study shows that fasciolosis is the most important parasitic disease in cattle, since it affects a digestive gland that is very important in vertebrates, the liver, which performs many vital functions such as metabolic function, so this research establishes the metabolic changes that animals experience according to the degree of infestation, and these damages are more significant in males than in females, in addition, fasciolosis by Fasciola hepatica, once it infects the liver, triggers a series of pathological diseases and these diseases produce alterations in the processes productive and reproductive. However, for the early diagnosis of fasciolosis it will depend on the ecological zone where the livestock system develops, if it is endemic to Fasciola hepatica and if there are also intermediate hosts of this parasitosis. For its detection it is necessary to implement diagnosis, prevention and control programs, avoiding the great economic losses caused by fasciolosis in cattle.

\section{Acknowledgements}

This project was financed with the laboratory's own resources through continuing education courses and with funds from the Office of the Vicerector for Research and Postgraduate Studies-VIEP-BUAP and with support from the Faculty of Biological Sciences of the Benemérita Autonomous University of PueblaMexico, for allowing us to use its facilities and in collaboration with livestock producers and municipal traces of various municipalities at the federal level. 


\section{Literature Cited}

Caicedo R. R.E., Torres Beltrán A., Hernández, Zepeda J.S., Resendiz Martínez R., Pérez Y Terrón. R. and Cabrera Bautista E. 2009. Effects of $\beta 2$-agonistadrenergic in the diagnosis of fasciolosis in animal ruminant Bos indicus $X$ Bos taurus, in the State of Puebla, Mexico. In International Symposium on sustainable Improvement of animal production and heal th. FAO/ IAEA, Vienna, A ustria, Vol1: 183-187

Caicedo Rivas, R.E.; J. Dimas Ríos; A. Torres Beltrán; S.V. Martínez Badillo; R. Pérez Aviles; J.S. Hernández Zepeda y R. Reséndiz Martínez. 2010. La fasciolosis como ecopatología que afecta la productividad ganadera en el Estado de Puebla, México. En XI Symposia Iberoamericano sobre Conservación y Utilización de Recursos Zoogéneticos. Joao Pessoa-Paraíba, Brasil. ISSN: 2179-1961. Pág.395-399

Caicedo Rivas R. E.; M. Paz-Calderón Nieto and S. V. Badillo M. 2011. Clenbuterol ( $\beta 2$-agonista adrenérgico), enmascara las patologías hepáticas en bovinos. Revista AICA (Actas Iberoamericanas de Conservación animal), (1):327-331.

Chirinos A.R. and N.I. DE Chirinos. 1993. Evaluación Evaluación de los efectos de la distomatosis hepática bovina sobre la eficiencia reproductiva y producción lechera. Rev. Científ. FCV-LUZ. III, 35-45.

Dalton J.P. (editor) 1999. Fasciolosis. Dublin, Irlanda. CABI International Publishing.

Guy W., V. Rajan, CH. Veetta and K. Rajender. 2001. Laparoscopic appearance of Fasciola hepatic infection. Gastrointestinal Endoscopy; 53, 668-671.

Jemli M.H., J.P. Braun, P. Dorchies, S. Romdhane and M. Kilani. 1993. Exploration biochimique et hématologique chez l'agneau infesté expérimentalement par Fasciola hepatica. Recueil de Médecine Vétérinaire 169, 241-249.

Loyacano A.F., J.C. Williams; J. Gurie and A.A. Derosa. 2002. Effect of gastrointestinal nematode and liver fluke on weight gain and reproductive performance of beef heifers. Vet. Parasitol. 107, 227-234.

Mas-Coma S. Human fascioliasis. pp. 305-322 in Cotruvo, J.A., Dufour, A., Rees, G., Bartram, J., Carr, R., Cliver, D.O., Craun, G.F., Fayer, R. and Gannon, V.P.J. 2004.(Eds.) World Health Organization waterborne zoonoses, identification, causes and control. London, IWA Publishing, Alliance House.
Mas-Coma S. 2005. Epidemiology of fasciolosis in human endemic areas. J. Hel minthol. 79, 207-216.

Mas-Coma S., M.D. Bargues, M.A. Valero and M.V. Fuentes. 2003. Adaptation capacities of Fasciola hepatica and their relationship with human fascioliasis: from below sea level up to the very high altitute. pp. 81-123 in Combes, C. and Jourdane, J. (Eds.) Taxonomy, ecology and evolution of metazoan parasites. Vol. II. Perpignan, Perpignan University Press.

Olivares E. 1994. Paquete de diseños experimentales FAUANL. Versión 2.5. Facultad de Agronomía UANL. Marín, N.L.

Ortega V.; R.E. Caicedo; J.S. Hernández; R. Resendiz and A. Ramírez. 2007. Fisiopatología hepática en bovinos (Bos taurus $X$ Bos indicus) con fasciolosis en el Estado de Puebla. Memorias del L Congreso Nacional de Ciencias Fisiológicas, Puebla, Pue., México.

Paz-Calderón Nieto, M.; R.E. Caicedo Rivas Y B. Hernández Pérez. 2011. Efecto del clembuterol en los niveles de fosfatasa acida "Fracción Prostática", en bovinos machos. Revista AICA (A ctas Iberoamericanas de Conservación animal), (1):136-140

Poitu I., E. Baeza and C. Boulard. 1993. Analysis of the results obtained using a technic of experimental primary infestation with Fasciola hepatica in the rat. International Journal of Parasitology; 23, 403-406.

Rangel Ruiz, L.J. y E. Martínez Durán. 1994. Pérdidas por decomiso de hígados y distribución geografica de la fasciolasis bovina en el Estado de Tabasco, México. Vet. Mex. (25(4), 327-331.

Robles C. A. 1998. Enfermedades Clostridiales del Ganado. 1a. Edición. Argentina. INTA.

Saavedra Rodriguez, A.; R.E. Caicedo Rivas; PazCalderón Nieto, M. y Estrada Poblano, M. 2019. Physiological effect of $\beta 2$-agonist adrenergic "Clenbuterols", in cattle Bos taurus X Bos indicus, in the State of Puebla, México. Agroproductividad: Vol.12, Num.6, pp. 63-68

Valero, M.A., M. Navarro, M.A. Garcia-Bodelon, A. Marcilla, M. Morales, J.L. Hernández, P. Mengual and S. Mas-Coma. 2006. High risk of bacterobilia in advanced experimental chronic fasciolosis. Acta Tropica 100, 17-23. 